\title{
Listening to Red
}

\author{
SINAZO MTSHEMLA \\ University of Fort Hare \\ GARY MINKLEY \\ University of Fort Hare
}

HELENA POHLANDT-MCCORMICK

University of Minnesota

Following a distinction John Mowitt draws between hearing (and phonics), and listening (and sonics), this article argues that the dominant notion of listening to sound was determined by the disciplinary framework of South African history and by the deployment of a cinematic documentary apparatus, both of which have served to disable the act of listening. The conditions of this hearing, and a deafness to a reduced or bracketed listening (Chion via Schaeffer) that would enable us to think the post in post-apartheid differently, is thus at the centre of our concerns here. We stage a series of screenings of expected possible soundtracks for Simon Gush's film and installation Red, simultaneously tracking the ways that sound - and particularly music and dialogue - can be shown to hold a certain way of thinking both the political history of South Africa and the politics of South African history. We conclude by listening more closely to hiss and murmur in the soundtrack to Red and suggest this has major implications for considering ways of thinking and knowing.

\section{Toyi-toying with the Song?}

An absence and a silence, or silences. ${ }^{1}$ Or so it seems.

During our first encounter watching the film Red, 2014, made by Simon Gush in collaboration with James Cairns, we were immediately struck by the absence of a music soundtrack. Red, one of the central components of Gush's installation Red, at the Ann Bryant Art Gallery, is ostensibly a documentary about the building of the red Mercedes for Mandela and the subsequent 'wildcat' strike that resulted in the dismissal of over 500 workers from the Mercedes plant in East London in 1990. The film combines footage of the plant, dock and surrounding city with interviews with key protagonists also filmed in East London and Johannesburg in 2013 (24 years after the event).

1 Both Sinazo Mtshemla and Gary Minkley wish to acknowledge the financial support of the NRF and the SARChI Chair in Social Change at the University of Fort Hare (UFH). 
We had variously imagined, before viewing the film, that it would be accompanied by a phonics filled with songs of umzabalazo (struggle) and toyi-toyi. It is, after all, a film, starting with its evocative title, ostensibly about black working-class struggle and 'freedom'. Furthermore, when Thembalethu Fikizolo, the first interviewee to speak in Red, summons up memories of the strike, they are of workers 'toyitoying' and singing in the plant as key signifiers of 'militant revolution'. In our mind's eye (and we will return to this), we felt as if something was amiss in the film - it sounded too quiet, almost too silent for what was being spoken about. ${ }^{2}$ What, in the Red soundtrack, with its mundane and everyday noises of the East London CBD, the waves of the sea, or even factory sirens, interrupted only by 'still' 3 personal narratives of recall, resonated with the events of 1990 ? In what ways could we even begin to hear the stories being told about these moments, in the absence of actual 1990 footage, and without the expected sounds and songs of struggle to at least situate the moment? Seemingly, then, no musical soundtrack. And no archival soundtrack. An apparent, evident silence, then, echoing in a seeming absence.

This silence resonates with three anticipated contexts. Firstly, the film's content, specifically its political history, generates an expectation that the soundtrack will necessarily draw on the documentary archive and performed music of liberation. Secondly, we are acutely aware of the availability of this music soundtrack, traced through the South African documentary film tradition, particularly as it relates to struggle, or resistance documentaries, and the central role ascribed to music and song in this revolution. And thirdly, a related, perhaps parallel expectation is evoked through the naming of this installation and its film as Red. Here, perhaps, the auditory space would have connected to a wider, global soundtrack of revolution, tracked through the music of socialism and liberation.

Maybe, though, also a fourth context, imagined through a different prevailing reading of 'red' as 'tribal', set in opposition to 'schooled' (modern) within the major anthropological work undertaken in the city, Phillip and Iona Meyer's Townsmen or Tribesmen. Red and schooled, the apparently localised versions of self-describing a subject position, could have synchronised Red to a set of indigenous music recordings' made at the same time as the Meyers recorded their field work in the 1950s and early 1960s, marking a different kind of societal 'revolution', simultaneously seen as 'indigenous' and as beyond the political. But that argument lies beyond the scope of this article.

Rather, our starting point, in outlining these contexts - to the extent that we have claimed that such contexts would, or should, 'reflect' content and explanation - is itself a screening of a problem. As John Mowitt compellingly argues in Sounds: The Ambient Humanities, a 'set of theoretical habits grounded in the paradigm of visualism' and the problem posed by the concept and disciplinary deployment of the

2 Clearly, we were drawing on the popular conceptions of scholars that speak to the protest or struggle song as being an instrumental tool in the display of solidarity and as common cause for working-class and popular nationalist struggle in South Africa at this time.

3 Stillness is also the peculiar impression evoked by the filmography of Red with its video footage of East London street- and harbour scenes in which the camera rarely moves within segments. 
gaze, has legitimated a 'systemic foreclosure' of thinking differently with, and about sound. ${ }^{4}$ In particular, we want to try and counter-track the ways that sound - and particularly music and dialogue - can be shown to hold a certain way of thinking both the political history of South Africa and the politics of South African history.

One important dimension of this discussion, staged by our own screening of an expected soundtrack, is the tendency to treat the soundtrack, especially in film studies, as the locus of music. Even dialogue, so magnetised by the images of mouths in motion, is forgotten. As Mowitt, but also Lastra and Goldmark et al. ${ }^{5}$ have pointed out, this staging of the cinematic apparatus as a voice box, particularly in documentary film where the tendency is to join music and voice precisely in song, is symptomatic of this tendency, and the privileging of song, and of what Lastra would call the privileging of 'intelligibility' (telephonic) over 'fidelity' (phonographic). However, as Lastra also argues, these approaches are not just nested within each other, nor do they they simply relate 'event' to 'structure.' Instead, the signs of these sounds are what is at stake, rather than the sounds themselves. For our purposes, it is his discussion of how a perceived 'naturalness' comes to be correlated '... with the presence of reflected sound, while "articulation" was associated with direct sound' that is important. Stated differently, spatial specificity and naturalness - fidelity sound - can be linked to certain forms of unintelligibility, while intelligibility has analogs in the case of sounds that are 'recognisable' and 'identifiable. ${ }^{6}$ Or, drawing on Mowitt, in what ways does the phonic and its hearing come to stand for the sonic and for the more necessary act of listening: or why does the song come to stand for the recognisable and identifiable of politics and resistance? This article will suggest that the dominant notion of listening to sound was determined by the disciplinary framework of South African history and by the deployment of a cinematic documentary apparatus, both of which have served to disable the act of listening. The conditions of this hearing, and a deafness to a reduced or bracketed listening (Chion via Schaeffer) ${ }^{7}$ that would enable us to think the post in post-apartheid differently, is thus at the centre of our concerns here.

Relatedly, John Mowitt has proposed that '... [p]erhaps the problem of silence uniquely traces the discursive barrier between the potential and the actual in what can be written about sound... we come to the unintended through the intentions of others'. In this sense, we want to begin to think, listen, if not actually with (as his is a much bigger, more extensive and nuanced attendance), but at least alongside Mowitt, and sample his 'audit' of 'inscription', defined by him as '... the process through which music - both as musicological construct and as performance practice - [but also sound] can be said to "echo", or otherwise belong to its moment, its time and place."

More expansively, as part of an extended engagement with the question of 'sounds', Mowitt has proposed that we think this question through the concept of

\footnotetext{
J. Mowitt, Sounds: The Ambient Humanities (Oakland: University of California Press, 2015), 8.

D. Goldmark, L. Kramer, and R. Leppert (eds), Beyond the Soundtrack: Representing Music in Cinema (Berkeley and Los Angeles, University of California Press, 2007).

6 J. Lastra, 'Fidelity versus Intelligibility', in J. Sterne, ed, The Sound Studies Reader (London and New York, Routledge, 2012), 248-253.

7 M. Chion, Audio-Vision: Sound on Screen (New York: Columbia University Press, 1994).

8 Mowitt, Sounds, 100.
} 
audit. He insists that we need to attune to the way in which '... materiality is questioned differently by being approached through sound or through a problematic in which the sonic and phonic are allowed to sound without drowning each other out.' As such, he argues, 'more precisely' we need to attend to '... how to traverse the faculty of hearing with the angle, the posture of listening, [for] it is here that the audit serves as a coherent analogue to the gaze..$^{10}$ Mowitt, then, in what is a remarkable series of attunements to echo, whistle, whisper, gasp, silence and 'tercer sonido, ${ }^{11}$ traces not 'how we situate sounds but how sounds situate situating', stirring (urging/ prompting/provoking) us to recognise 'situating as a problem.' ${ }^{12}$

This article, then, is a rather more modest attempt to sample sounds from Mowitt's concept of the audit and to try to both hear and listen to the phonic and the sonic in relation to Red, primarily in relation to the film, but also in relation to the installation. In many respects, it is a more pedantic endeavour, seeking to hear Red in relation to the sound of revolution, and in turn, through the intentions of others, while listening to its situated silences and unintended echoes of otherwise belonging. As such, we tune in to context in some detail in order to think about and problematise the 'ways of knowing revolutionary context and the sounds it purports to know.' ${ }^{13}$

Notated differently, what does the absence of a synchronous and music soundtrack (conventionally defined) articulate about its associative echoes that might enable us to think - through sound, through hearing, but also through listening to revolution in Red - a different way to situate situating ? In this we proceed somewhat counterintuitively, attempting to hear and to listen - to audit - this soundtrack precisely through providing and detailing a number of possible sound contexts (of and for this sound given its 'absence'), attempting to outline the sounds these contexts purport to know and to suggest some of the effects these might have when both heard and more importantly, listened to. For as Mowitt argues, sounds are '... provocations to readings, especially readings that find problems not only in or with other readings, but with the conditions and limits of reading itself.' ${ }^{14}$

\section{A Forward-track}

Sean O'Toole's review of the first installation of Simon Gush's Red at the Goethe Institute in Johannesburg in April 2014 was entitled '[T] his is the work of a revolution'. And it is worth noting, simply as point of connection, that the Mail \& Guardian newspaper's online version used an image - of Philip Groom and Nelson Mandela in the hand-over of the car - that is at the centre of the Mercedes-Benz SA (MBSA)produced short commercial film, Labour of Love, and that is not in the Red installation.

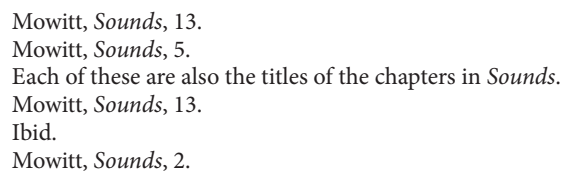


O'Toole identifies the film component of Red as a 'new documentary' and importantly turns to sound to articulate his reading of the 'exhibition'. Drawing on the narrative of one of the interviewees in the film, O'Toole writes:

'It was crazy,' recalls Groom in a new documentary film - part of an exhibition titled Red - by artist Simon Gush and collaborator James Cairns. 'People were dancing, singing, ululating. It was basically a party'.

Then came Monday. Work. 'What now?' Groom and his co-workers wondered as they returned to the assembly line. ... Red also explores what happened after Mercedes-Benz workers answered the question 'What now?' ... In short, things got ugly. ${ }^{15}$

Labelling Gush's practice as 'neo-conceptualist', O'Toole tracks the installations' concern with 'speculative reconstructions' of the beds and uniforms, and concludes that '[a]rt about politics is a high-wire act. It must balance creative expression with a diagnostic function. ... [Gush] may just be our Vladimir Mayakovsky, an art worker for the revolutionary avant-garde. At least, that's my diagnosis. ${ }^{16}$

We will return to this 'diagnosis', but first want to connect to 'dancing, singing and ululating' as the definitive sounds that accompany freedom. Perhaps, albeit debatably, this is best exemplified, on film, by Lee Hirsch's Amandla! A Revolution in Four-Part Harmony. ${ }^{17}$ More pointedly, though, Amandla! also ends with Mandela's release in 1990 and it is the echo to O'Toole's referencing of Groom's words - 'dancing, singing and ululating' - which resonates as a determinant reading of music and revolution in South Africa.

The title is inspired by musician Abdullah Ibrahim's statement for a particular strand of South African uniqueness, that it is 'the only revolution anywhere in the world that was done in four-part harmony.' ${ }^{18}$ Hirsch, an American filmmaker apparently became 'captivated with the music he heard in the background of news reports featuring demonstrations and riots in South Africa. People were being beaten by the police, but Hirsch says "they were singing"'. ${ }^{19}$ It is also possible to trace this connection between music, resistance and the very 'emergence' (following Maingard) of anti-apartheid documentary filmmaking to Come Back Africa, ${ }^{20}$ where the critique

15 S. O'Toole, 'This is the Work of a Revolution', Mail \& Guardian, 4 April 2014, http://mg.co.za/article/2014-04-03-this-is-thework-of-a-revolution, last accessed 6 August 2016. It is worth noting that in-between the release of Mandela on 11 February and the 'ugly' strike in August 1990, O’Toole relays how the documentary recounts the building of the red Mercedes for Mandela.

16 O'Toole, 'Work'.

17 L. Hirsch, Amandla! A Revolution in Four-Part Harmony, (US: ATO Pictures/ South Africa, Kwela Productions, 2002). The film was made with funding from the Ford Foundation and HBO films and most directly authorises the central role of music in the struggle between the 1940s and the 1990s. Vusi Mahlasela is music advisor. It also positions a set of musicians and songs within a liberatory canon: including Mahlasela, Hugh Masekela, Miriam Makeba, the choir, and the kwela/mbaqanga guitar as defining sounds.

18 Cited in C. Moyer-Duncan, 'Representations of Apartheid and Resistance in Documentary Film', History Compass, 10, 2, 2012, 105-118. (112)

19 Moyer-Duncan, 'Representations', 111.

20 J. Maingard, 'Trends in South African Documentary Film and Video: Questions of Identity and Subjectivity', Journal of Southern African Studies, 21, 4, December 1995, 657-667. (657) Indeed, Come Back Africa operates as the musical-resistance-liberation template for Amandla!, from its use of 'archive footage' of Makeba, through to its centering of Sophiatown and its removals, including into exile, as collective South African space. 
of apartheid was framed through the 'vibrant' cultural (musical) life of Sophiatown. In Amandla!, Moyer-Duncan observes that Hirsch 'celebrates music as an important component of resistance to apartheid' and 'uses music to drive the film's narrative by incorporating archival footage of concerts and political rallies; performances in community and studio settings produced for the film; and informal incantations of the musicians and activists featured in interviews'. She concludes that ' $[\mathrm{b}] \mathrm{y}$ featuring unknown activists alongside famous musicians, and using their voices as the voices of history, Hirsh offers a more democratic view of history, music and cultural production $^{21}$ and thus a '... compelling articulation of the potential for music to be a subversive weapon, a mobilizing force, a source of comfort and an emotional release in the context of struggle.22

To be sure, Amandla! has been subject to a range of criticisms, from its 'outsider' status, being 'oversimplified' for an American audience, through to declaring it a conservative musical project 'disempowering music' and South Africa's 'musical pasts. ${ }^{23}$ More particularly, Barnard has argued that it is parochial, essentialist and reductionist, ${ }^{24}$ while Mtshali and Hlongwane have relatedly argued that it privileges hegemonic groups within the ANC, portraying it as a 'monolithic and univocal organisation' and therefore that it fails to take account of what they call the 'multiaccentuality of the liberation songs. ${ }^{25}$ Dalamba, most effectively, extends these critiques, arguing that Amandla! reduces the liberation struggle to race, homogenises time and space around the Sophiatown removal narrative, 'stages' multiple voices and 'imitates' a democratic historical record for music as liberation. More critically, she argues rather that Amandla! 'disempowers', it is one-dimensional and in its privileging of Makeba and Masekela and music in exile, it assumes an authority that locates this music within the 'global popular imagination', and therefore constructs 'representative allegories of correct historical, musical, and political practice. Thus, for Dalamba, there is a 'homologizing ideology at work in Amandla!' which 'fixes music and musicians' and generates further reifications, reinscribing 'personal chronotopes as collective remembrance' from within a 'national biography' and as the 'defining events for South African popular music and for the fabled South African musician-in-exile. ${ }^{26}$

The overall point for us, though, is that the music of Amandla! and related songs remain the 'source music' for hearing liberation. The critiques continue to rehearse music as the backing track for liberation, albeit while asserting that struggle music needs to be necessarily located within 'historically emergent social and political meanings', rather than as part of 'a bounded and complete epoch. ${ }^{27}$ This resort to

\footnotetext{
Moyer-Duncan, 'Representations', 111.

Moyer-Duncan, 'Representations', 112

Moyer-Duncan, 'Representations', 112; L. Dalamba, 'Disempowering Music: The Amandla! Documentary and Other Conservative Music Projects', Safundi: The Journal of South African and American Studies, 13, 3-4, July-October 2012, $295-315$.

24 Barnard, Review. 'Amandla!: A Revolution in Four-Part Harmony', African Arts, 36, 2, 2003, 8-87; as also summarised in Dalamba, 'Disempowering', 311.

25 K. Mtshali and G. Hlongwane, 'Contextualizing South Africa’s Freedom Songs: A Critical Appropriation of Lee Hirch's Amandla! A Revolution in Four-Part Harmony', Journal of Black Studies, 45, 6, 2014, 507-527. (524-5)

26 Dalamba, 'Disempowering', 311.

27 Dalamba, 'Disempowering', 312.
} 
context to provide nuance, specificity and complexity, however, remains bound to the four disciplines of history, sociology, politics and music studies, reproducing the attempts to harmonise struggle, exile, non-racialism, the local and the global, the individual and the collective, the unique and the common - to complete the democratic subject. Even if, as Dalamba poetically concludes, '... the four-part harmony that sang of revolution has not closed at a perfect cadence after all, ${ }^{28}$ the rhythm of sounds within which that music sang of revolution as both backing- and forwardtrack remains, heard in falling tones and not erased.

To hear a more explicit non-diegetic non-visual connection to Red, consider the National Union of Metalworkers of South Africa (NUMSA) ${ }^{29}$ 'view' of its own soundtrack, Solidarity Forever, recorded in 2003. Under the heading 'Dancing to our struggle, the union self-reviewed the event in the following terms:

Recorded live at the [NUMSA] union federation's eighth national congress in September 2003, Solidarity Forever brings together the cream of South Africa's music industry. Lending their vocal cords to the project are musicians like Jonas Gwangwa, Letta Mbuli, Busi Mhlongo, Vusi Mahlasela and Jabu Khanyile. Under Hugh Masekela and Khaya Mahlangu's musical directorship, the album features a 13-piece band. Adding their voices are 100 South African Democratic Teacher Union (Sadtu) and Police and Prisons Civil Rights Union (Popcru) choristers. 'The CD's release honours artists who over the years have written lyrics on workers' suffering and evoke dreams of a better life,' said Cosatu general secretary Zwelinzima Vavi at the album's launch in December. Steeped in the country's popular music traditions, the lyrics in the songs refer to how diseases such as retrenchment, unemployment and HIV/Aids are feeding like locusts on the nation's social fibre. Despite dealing with serious issues, the music in the album is joyous and danceable. Being the bedrock of South Africa's exploitative and racialised capitalism, conditions that face miners feature prominently in the album. Three songs in Solidarity Forever talk about the migrant labour system and the brutality meted out to miners. ${ }^{30}$

\section{A Song-track - Labour of Love}

If Red did have a diegetic soundtrack, what might it sound like? ${ }^{31}$ To think about this, we turn to the short film Labour of Love, produced by Ginkgo Agency in Cape Town for MBSA in 2013.

28 Dalamba, 'Disempowering', 313.

29 For a considered discussion of schisms within the labour movement that played out during the wildcat strike at Mercedes in 1990, see also Leslie Witz, this issue, and below.

30 See NUMSA, 29 February 2004, http://www.numsa.org.za/article/dancing-to-our-struggles/, last accessed 13 September 2016. No author.

31 Red does have some sound whose source is visible on the screen. In some scenes the sound of the scenes filmed - a rumbling motor, a truck door slamming - is present, even with the overlay of the interviews, but it is not music (we return to this below). 
Janet Cherry has provided a rather different reading of liberation songs, based precisely on local context. In Emzabalazweni (In the Struggle): Singing the Language of Struggle, Past and Present, Cherry traces the 'discourses reflected in liberation struggle songs from the 1980s through to the present day' and draws on significant Eastern Cape examples. ${ }^{32}$ She argues that songs were often used to make tactical political interventions, but that, in 'contrast to analyses which emphasise racial identity in past and present discourses', in these songs the 'dominant discourses in the past [from c1980 up until 1994] were inclusively nationalist, concerned with citizenship and as the decade wore on, more populist and militant ...'. ${ }^{33}$ She concludes that the dominant themes of these liberation songs were of 'democratic citizenship', that they 'reflected a non-racial ideal' and that they were essentially 'anti-colonial', anti-apartheid and anti-state violence rather than 'ethno-nationalist. ${ }^{34}$

As Ciraj Rassool has argued (this issue), the short film Labour of Love was made 'within a Mandela-Mercedes-conservation nexus of business, development and stewardship ${ }^{35}$, and more widely appropriates the event of the making of the red Mercedes as reconciling race and class and as an embryonic mutual space enacting and anticipating the new nation. While this is significant (and is explored in more detail in Rassool, this issue), it is important for us for a different reason. Apart from the identification of the names of the three individual narrators, all of whom are seen and heard to be associated with Mercedes-Benz as 'workers', Labour of Love is practically silent on the details and the names of those involved in the film's actual production, except to claim a purpose: 'South Africa, 1990. A community of factory workers gathered to handcraft a Mercedes-Benz for a man who had spent the last 27 years in prison. A man they had never laid eyes on. A man who changed the course of history. This is their story. ${ }^{36}$ Thereafter we are told, through sub-titling, the names of Lennox Dwangu, Ronald Fraser and Philip Groom. And at the end we read: 'South Africa: Together We are Better.' That's it. No credits, no acknowledgements, no director; filmmaker, camera, sound, editing? Nothing more.

The absence of this information potentially silences difficult, tricky, indeed, contradictory readings, while authenticating the story it tells through its use of 'real' footage. Who was responsible for the filming inside and outside of the plant in 1990 ? How much filming went on then, and why? Or of Mandela? Where? When? Who took the photograph of Groom and Mandela, the same photograph used by the Mail \& Guardian in 2014, and simply credited to AFP $?^{37}$ And the 2013 footage? Who composed the music soundtracks? Who did the cutting and splicing? And are the scraps of 1990 diegetic sound incidental, haphazard, driven by visual imperatives, or more carefully edited?

J. Cherry, 'Emzabalazweni: Singing the Language of Struggle, Past and Present', in M. N. Dedaic, Singing, Speaking and Writing Politics: South African Political Discourses, (Philadelphia: John Benjamins, 2015) 221-246.

33 Cherry, 'Emzabalazweni', 221.

34 Cherry, 'Emzabalazweni', 243-244.

35 C. Rassool, (16). For a fuller discussion of the film and its production, see the essay in this volume.

36 Labour of Love. Ginkgo Agency, 2013. http://www.ginkgoagency.com/case-studies/mercedes-benz-labour-of-love, last accessed 11 August 2016.

37

O'Toole, 'This is the Work' 
Undoubtedly, though, in its multiple referencing of song and dance, ululation and toyi-toying, this film articulates 'glorious celebration' from the site of labour as its core message of persuasion. In this respect it affirms Nichols, who argues that 'the centrality of argument gives the soundtrack particular importance in documentary ... most documentaries still turn to the soundtrack to carry much of the general import of their abstract argument. ${ }^{38}$ As Rogers has relatedly observed, for Nichols 'the soundtrack resonates with the spoken word in the form of voice-over commentary or dialogue taken on site. But, more significantly, it is the unspoken moments that hold the most power in the construction of documentary persuasion..$^{39}$ In Labour of Love it is the song and the often soundless act of singing, but viewed from within the filmed world of the 1990 Mercedes-Benz assembly plant, that together with the non-diegetic and un-named music soundtracks, make up its 'unspoken moments' or sequences.

These are significant. There are two added music soundtracks. The one, which begins 1:50 into the film, swells around the archival image of the plant, viewed firstly through the fluttering of five Mercedes flags and then cuts to the plaque ('Dr N Mandela's Car') made by the workers to be placed on the red Mercedes. The music is formal, almost melancholic with its minor elements, and driven by classical strings. It is the music of Mercedes-Benz, the company, but perhaps as it used to be, before this 'labour of love' moment, heard as the counterpoint to the songs on the factory floor. It inserts Mercedes-Benz into the story as co-producers of this moment and this car of change. The second music soundtrack, 3:42 in, is located around the release of Mandela, and the shift is to kwela guitar as a key 'source music' of freedom. As the classical fades into the African, and the voice-over of Philip Groom sounds non-racial change and freedom, so too is the Mercedes-Benz company repositioned within this event: the soundings of 'together we are better'?

In its short 4:44 minutes, though, it contains eight brief sequences and segments (some no more than three to five seconds) of 1990 video/film colour footage and sound, largely in the form of singing - first in the production line, and subsequently in the transportation of the red Mercedes out of the factory to being handed over to Mandela. The final sound from 1990 is an excerpt of Mandela speaking, overlapping with footage of the workers singing, and with the kwela guitar soundtrack, unidentified, but reminiscent of Vusi Mahlasela or Alan Kwela.

In this sense, Labour of Love provides fragments of what is often read as authentic, archival diegetic sound - the 'actual' sound of workers collectively singing in the Mercedes plant and in the delivery of the car. The footage, starting at 1:50, together with a montaged series of images of the production line, excerpts of the making of the plaque and then the red Mercedes (which, in Philip Groom's terms, was 'of our hands, of our own time'), anticipates this song footage. In the images of workers dancing/toyi-toying, fists raised, clearly singing, the sound is edited out except in the

38 B. Nichols, Representing Reality: Issues and Concepts in Documentary (Indiana: Indiana University Press, 1991$), 21$.

39 H. Rogers, 'Introduction: Music, Sound and the Non-fiction aesthetic', in H. Rogers, (ed) Music and Sound in Documentary Film (New York and Oxon: Routledge, 2014), 7. 
last second, when it is replaced by a classical, formal, minor-chord melancholic music soundtrack and by the talking head voiceover of Lennox Dwangu, saying, 'If you are finished your part then you do the singing, and if you have to do your part, you have to do your part and after you've finished your part and you got time to sing, then you do the singing. ${ }^{40}$

Thereafter, in the seven segments of archival footage that contain sound, it becomes possible to identify at least certain songs that were sung in the plant at this time, and which seemingly provide a more realistic and less speculative music soundtrack, a song-track. At 2:20 the footage features the workers carrying the car, marching and singing. It is the first time the voices of the workers are clear and there is no background music, nor voiceover. The song they are singing goes as follows in a call and response form:

\section{Call part: Hayaya iyooh! ${ }^{41}$}

Response part: Hayaya iyooh! (x 2) Hayi isoja!

It is just these two lines of call and response that are shown in the film. The full lyrics are as follows:

\section{Call: Hayaya iyhoo!}

Response: Hayaya iyhoo! (x2) Ha isoja!

Call: Isoja intwe ngalali (A soldier a thing that never sleeps)

Response: Hayaya isoja!

Call: Isoja ikomanisi (A soldier a communist)

Response: Hayaya isoja!

Thereafter, at 3:26, the footage used is of the red Mercedes being built for Mandela emerging from the assembly plant with the workers singing 'Sabela Uyabizwa', also in a call-and-response form. The two lines sung are:

Call: Uyibizwa! (You are being called!)

Response: Sabela uyabizwa! (Respond to the call!)

Lyrics to this song typically nominated Mandela, or a leader in the following manner:

Call: Nelson Mandela!

Response: Sabela uyabizwa (Respond, you are being called!)

Call: Uyabizwa! (You are being called!)

Response: Sabela uyabizwa! (Answer, you are being called!)

41 Where no translations are given, the song is more emotive than lyrical - an expression of sound rather than the people singing something that makes sense in words. 
At 3:54, the song-words 'Dubula ngesibham!' (Shoot with a gun!) can be heard after Groom has spoken about the significance of the colour red in representing not only NUMSA and the workers, but also the blood that was spilled during apartheid. The footage is of the red Mercedes-Benz moving in a public street, apparently on the way to the stadium and surrounded by many people, not only the workers, as in previous scenes. The ANC flag is raised over the body of the car. People are visibly singing and whistling. And finally, at 4:02, there is a collective sense of 'the people', not just workers toyi-toying and singing 'Hayayi hayayi hayayi iyhoo hayi!'. There is not enough footage to make out the actual song being sung, but the footage then cuts to the seemingly synchronous sound and image of Nelson Mandela making a speech or statement about the car. It is not clear, though, whether or not this is footage filmed at the Sisa Dukashe Stadium. Mandela says: 'On that special day, the workers of this company made a tremendous gesture that was convincing evidence that in South Africa there are many who are willing to work together and make sacrifices to build our nation' (our emphasis). Perhaps, more likely, it is an interview at the MercedesBenz plant. Does this matter?

In one reading, we could argue that the editing of the footage and the cutting of the songs to simple call-and-response utterances, consistently, without any other reference points - no soldiers, communists, guns - in other words without any references to militancy, reduces the songs to celebration, exuberance, singing and dancing. This is consistent with our reading of the persuasive intent of Labour of Love. But, as one of the few, perhaps the only, remaining sources for a synchronous hearing of the actual construction and transportation of the Mandela Mercedes in 1990, does it not call for a more careful, perhaps untimely, listen?

\section{Uncomradely Songs?}

Cherry has argued that liberation songs in the period between 1980 and 1994 followed if not four parts, then four stages: those harkening back to and associated with the re-emergence of Congress traditions of the 1950s in the early 1980s; those associated with building mass-based organisations in the early to mid 1980s; those associated with the insurrectionary years between the mid to late 1980s; and those associated with the period of transition from 1990-1994. ${ }^{42}$ Through a careful and convincing reading, Cherry tracks how these songs shifted in tone and form from hymn-like, reverent and sad, slow songs typifying the 1950s Congress traditions; to mass participatory songs; to more militarised $(\mathrm{MK})$ songs linked to defeating the apartheid state and identifying particularly homeland and local government 'collaborators'; to militant, up-beat and populist songs, advocating more direct action, all the while continuing to primarily call for the end of the apartheid state and its violence.

Importantly, Cherry also notes that songs are often used to make tactical political interventions and can 'play a divisive role. However, she traces this phenomenon 
much more to the post-1994 period, by which time, she argues, liberation songs had been 'recontextualised' around emerging class discourses and struggles within the liberation movement.

But to return to Mercedes-Benz and to 1990, after the building of the red Mercedes, the plant experienced what a recent commentator has called a 'revolt ${ }^{43}$ It is not necessary to explore this in any detail. Suffice to say, the revolt drew on long-established lines of political disagreement between the recently 'integrated' South African Allied Workers Union (SAAWU) members and NAAWU and related FOSATU unions as they merged into NUMSA (in 1989), and has been read as reflecting differences between the 'community' and 'shopfloor' unionism (of NAAWU/FOSATU) and thus also, in union registration debates, between general versus industrial unionism and, in the late 1980s, disagreements over centralised bargaining. ${ }^{44}$ Splits between workers intensified as conflict and emotion, which drew on long-standing intense political relations, became 'not comradely relations. ${ }^{45}$

In August, this led to the occupation of the Mercedes-Benz factory, starting with around 2000 strikers, but cohering around a core of around 500 workers after an initial period. Those not on strike left the factory, according to Forrest, '... amid heavy intimidation, to follow developments on their radios at home. After two weeks, the factory occupiers ... were evicted by the police and fired' ${ }^{36}$ As Forrest notes, though, the factory remained closed for a further seven weeks as strikers, NUMSA and management 'wrangled over conditions for a resumption of work and the reinstatement of the dismissed. ${ }^{47}$ In the end, 521 workers lost their jobs.

Routinely dismissed as 'factory tribalism' (see Witz, this volume) on the one hand, and alternatively, as opening up questions as to whether NUMSA had become a 'labour aristocracy' and was abandoning the socialist project it was hoping/committed to advance on the other, Forrest's retrospective reading provides the pre-dominant interpretation of NUMSA consolidation and shifting accommodation of capital and labour in the 'post-apartheid era'. ${ }^{48}$ Our trajectory into the 'revolt', though, is a rather more throwaway line in which Forrest writes, ' $t$ ] he dissident shop stewards agreed that they had made mistakes; that the central issue was to unify workers and respond to management; and that assaults, coffins, placards and songs insulting comrades should stop. ${ }^{49}$

Songs and acts and representations insulting comrades. This was widely reported on at the time. Not just insults, but attacks, divisions, derision and damage. The intense, dramatic conflict between workers and management that had marked the

K. Forrest, Metal that will not bend: National Union of Metalworkers of South Africa, 1980-1995 (Johannesburg: Wits University Press, 2011), 194.

44 Forrest, Metal, 194.

45 Forrest, Metal, 195. Mtutuzeli Tom described these relations as 'not comradely relations', and these were related to previous personal attacks and house bombings between Saawu, NAAWU and subsequently NUMSA.

46 Forrest, Metal, 195.

47 Forrest, Metal, 195.

48 Forrest, Metal, 195-199. Forrest elaborates on these shifts as evolving into a different project which was not the overthrow of capitalism but rather the co-determination of industries in partnership with capital, and to balance political and material interests.

Forrest, Metal, 197. The SALB has a similar sense of this process, where songs and actions became points of dispute. 
1980s was described as follows by Charles Nupen: '... workers with wooden AK47s [and bazookas] on their backs. At lunch time there were mock bayonet charges on effigies of management. White supervisors were carrying real weapons and the atmosphere on the shop floor was one of deep antagonism and hostility. ${ }^{50}$ In 1990 , though, in the midst of the strike, sleep-in and dismissals, the conflict shifted to being primarily among NUMSA members: between those not on strike and the striking workers.

From a series of interviews conducted in 1991, it is apparent not only that the singing of songs, accompanied by mock funerals and coffins, and intense moments of confrontation practically defined the months of the strike and its aftermath. It is also possible to trace, through the interviews, how the NUMSA shop stewards opposed to the strike mobilised songs at the Gompo Hall meetings in Duncan Village and in opposition to the striking workers. Interviewees particularly remembered moments outside the Gompo Hall, where the non-striking workers led by shop stewards Mtutuzeli Tom and Thembalethu Fikizolo organised counter-meetings, and encounters beyond the factory as explosive. While some also retained what Cherry has called the discourse of populist militancy, there was the tendency for them to resort to more 'governing' songs, anticipating the end of apartheid. Interviewees remembered songs like 'Dilika we Ntaba' (Come down the mountains, so that we see Mandela), 'Umkhonto We Sizwe' (Spear of the Nation) and 'Saphela Isizwe' (The nation is being destroyed). They also recalled the song 'We'll never compromise; we'll never abandon the struggle. ${ }^{51}$ Perhaps, then, these songs also reflect the position that the non-striking workers occupied, attempting to legitimate their own actions, while maintaining their own centrality in the plant. As such, their songs and their political agency might also be considered as reflecting an attempt at the recontextualisation of the worker in relation to capital and to liberation. But in articulating and maintaining internal divisions of conflict, the liberation song more generally also became detached from the sound of revolution.

In this moment, the liberation song was not so much recontextualised, but decontextualised and displaced. In the midst of this, the liberation song became uncomradely. From the interviews, the following songs in particular were remembered as practically becoming anthems for the striking workers and therefore also as increasingly unacceptable for those not on strike. The first, Niyaboyika na? (Are you afraid of them? $)^{52}$ was directed at the non-strikers, and is significant in suggesting both the transfer of militancy towards them and in the naming of them as amabhulu (boers/Afrikaners).

Niyaboyika na? (Are you afraid of them?)

Asiboyiki. uProf uzoba nathi (We are not. Strength will be with us.)

C. Nupen, 'Mediation and Conflict Resolution in South Africa and Southern Africa', Accord, AJCR, 2012/13, 2 December 2013, http://www.accord.org.za/ajcr-issues/\%EF\%BF\%BCmediation-and-conflict-resolution-in-south-and-southern-africa/, last accessed 23 August 2016, 91.

51 Interviews, Gary Minkley with M.T and S.N., 22 June and 26 June 1991 respectively.

52 Interviews, Gary Minkley with N.M., M.T., M.G., M.M., 21-24 June 1991. 
That' Ibhazuka (Take a bazooka.)

That' igrineyida (Take a grenade.)

Ulalel' amaBhulu (And kill the boers/Afrikaners.)

The second maintained a similar theme, and recalled the fragment of song heard in the Labour of Love film. 'Isoja' was one version. Another was 'Sinik' umkhonto lo' (Give us the spear), as was 'Thina singama cadres' (We are the cadres, we shoot with a tank, we shall govern, we shall win). Two other songs, though, usually directed at apartheid state officials, like Adriaan Vlok or Magnus Malan, and against 'collaborators' like Lennox Sebe and Oupa Gqozo of the Ciskei bantustan, instead began to locate Tom and other NUMSA shop stewards as guilty. One is the song 'Mvezeni simbone' (We want to see him; show us). ${ }^{53}$ The other was 'Ligcwele iimpimpi' (There are many spies in our country, We will fight, We will fight, Until we get our country back) which similarly identified the NUMSA opponents as 'spies.54

Listen back to the NUMSA soundtrack of Solidarity Forever in 2003 (above). There is a sustained sense in which the phonics of liberation songs are re-asserted as addressing 'workers' struggles and dreams of a better life' and are accompanied, at least in the anonymous reviewer's hands, by lyrics that '... refer to diseases such as retrenchment, unemployment and HIV/Aids that are feeding like locusts on the nation's social fibre. We will return to the locust, but is there not something worrying, indeed perhaps alarming when this view within and about NUMSA, 'dancing to our struggles', is set paratactically near to the 1990 strike? To sample from John Mowitt, it should prick one's ears to more than just the phonics of different contexts, but to listen with caution and care and with considerable hesitation and open up ways of knowing and the sounds it purports to know.

If the synchronous liberation song sounded freedom in the building of the red Mercedes in Labour of Love, a few months later these same songs sounded a revolution falling apart. Or perhaps they were always apart, an echo that is a foundational distortion, a delay - missing from the source. Perhaps, then, a sound reason for Simon Gush to not to have included diegetic source songs in the film, and installation Red.

\section{An Unheard Melody - 'Pondo Blues'}

In 1992, Gary Minkley visited Thozamile Gqweta, the president and a founding member of SAAWU in 1978, at his home in Mdantsane. They talked about SAAWU, about his life and about East London and spoke, too, about the Mercedes strike, although he was not involved. In the course of the discussion, it emerged that he had a love of music and had played in a local jazz band, the Trutones, in the 1970s. Somehow they got to hypothesising: if SAAWU had a soundtrack - a song that would define it - what it would be? Minkley recalls that Gqweta, smiling, got up and put Eric Nomvete's 
'Pondo Blues' on the record player, scratched, played to death, crackling. Sound and sense intersected. But he also recalls that Gqweta said something puzzling. He said, 'It's as much in the words, as in the sound. Listen!' ${ }^{55}$ Nomvete's version, though, had no words. Minkley recalls that they laughed together and moved on, him deaf to the possibilities opened up in that formulation and only hearing the cacophony of politics playing in his head. But Minkley remained puzzled by his formulation and frustrated that he had never followed up on what Gqweta had meant. In sharing this moment, it seemed to resonate with this article and with all three of us in useful ways.

In a recent dissertation, Sazi Dlamini offers a relatively detailed analysis of 'Pondo Blues' by Eric Nomvete's Big Five Band, which was performed and recorded at the 1962 Cold Castle Festival at the Moroka-Jabavu stadium. ${ }^{56}$ Dlamini describes Nomvete as a Transkei-born saxophonist, bandleader and an East London-based social worker he lauds for what is deemed a 'remarkable exploration through jazz sensibilities, of elements of African indigenous musical particularity, in this case traditional Xhosa (Pondo) vocal polyphony and harmony.57

Importantly, though, the song, although titled in the recording as 'Pondo Blues', is also identified by Dlamini as 'Ndinovalo, Ndinomingi', and understood as being based on a traditional Xhosa drinking-song. ${ }^{58}$ The rhythm of 'Pondo Blues' is interpreted by Dlamini as an '... essential abstraction from forms of indigeneity as commonly practised by the majority of black South Africans.5 ${ }^{59}$ Xaba similarly suggests that:

When Eric Nomvete ... came on with his group, it was such an electrifying moment when he played 'Ndinovalo, ndinomingi'...Beer bottles started flying all over the place...because he invoked the spirit of the black man ... this is what we want to do! There is no need for us to go anywhere else but look into ourselves. (Ndikho Xaba, quoted in ABC Ulwazi: 2001). ${ }^{60}$

We do not wish to explore the work this invocation of an indigenous or essential black African context and 'spirit' entails and enables here. Aspects are addressed elsewhere by Mtshemla. ${ }^{61}$ The African indigenous particularity that Dlamini recognises in and ascribes to 'Pondo Blues' can be likened to, associated with and seen as resonating with the ethnomusicological work of Hugh Tracey located within the International

55 Interview, GM with Thozamile Gqweta, Mdantsane, 18 June 1992.

56 S.S. Dlamini, 'The South African Blue Notes: Bebop, Mbaqanga, Apartheid and the Exiling of a Musical Imagination', (D.Phil. thesis, University of Kwazulu-Natal, 2009), 159. According to Dlamini the 'Pondo Blues' rendition by Nomvete's band proved to be a welcome stepping away from the festival's repertoire of 'reworkings of standard American popular jazz and blues material'. Dlamini, Blue Notes, 159

58 Ibid.

59 Dlamini, Blue Notes, 168-169.

60 Dlamini quotes Douglas Ndikho Xaba, a percussionist and composer who had been in exile in the U.S. following a tour of the country by Union Artists' musicians in a musical based on Alan Paton's play Sponono, but here via an interview about how he remembers 'Pondo Blues' at the Moroka-Jabavu festival.

61 S. Mtshemla, 'Can there be African Time? Working uncomfortably with the concept time and its rhythms of irregularities in archiving of African music', paper presented at University of Minnesota International African Studies Conference, 'Fault Lines: Rethinking Temporal and Disciplinary Traditions in African Studies', University of Minnesota-Twin Cities Campus, 21-23 April 2016 . 
Library of African Music (ILAM) archive at this time. ${ }^{62}$ This archive too, has an association with and a working towards the need to 'expose' in his field recordings what Philip and Iona Mayer, in their major, then new urban anthropology of East London, called 'red' as against what they labeled as the 'schooled'. ${ }^{63}$ Neither do we think that this was what Gqweta had in mind.

Perhaps, though, we can again listen a little more attentively. It is certainly worth noting that as a drinking song, 'Ndinovalo, ndinomingi' becomes 'Pondo Blues' at the South African Breweries (SAB)-sponsored Castle Lager Music Festival, resonating with its sources. Here a drinking song decays into the Pondo rural and indigenous as it is displaced first into the 'beer halls' that are seen to define black, urban, workingclass culture after the 1920s. As an echo delayed, it is sounded again in Come Back Africa, Sophiatown and the Drum decade. And, decayed again, it turns into the sound of capitalist mass consumption in the SAB-sponsored music festival. Meanwhile, Nomvete's 'Pondo Blues' is heard as displacing into the 'spirit of the black man' where 'electrified', 'flying beer bottles'-like notes accompanied a presence of 'looking into ourselves' as authentic. Problems of hearing and what this song purports to know abound.

Its sound echoes, though, in a much more 'non-localizabile' sense. ${ }^{64}$ 'Ndinovalo, Ndinomingi' is also a song that Mtshemla's grandmother's, who is in her eighties, recalls playing frequently on the gramophone when she was growing up. She remembers these lyrics: 'Ndinovalo Ndinomingi mingi ingathi ndizokwaliwa' (I am nervous/anxious as if I'm going to be rejected) $)^{65}$. Perhaps, too, this was the recording that was made by Hugh Tracey (and archived in ILAM) in 1952, named 'Ndinovalo Ndinomingimingi' and listed as having been recorded under the Gallo Record Company label and performed by David Mdingi and Company?66 The song in this instance is accompanied by a piano and female voice singing and clapping: Ndinavalo Ndinomingimingi ngathi uzakundala (I am nervous/anxious as if you are going to reject me). Then a version of this song called 'Pondo Blues' (without words), is performed by Nomvete in 1962, and, according to him, recalls the failure of the 'parliament in the hills' and the Pondoland Revolt. ${ }^{67}$ Then, following Gqweta, it becomes his personal soundtrack for a dissolved and incorporated 'community union' and of SAAWU being transformed and dissolved into NUMSA.

Nervous. Anxious. Rejection? Inclusion? Belonging together or apart? Simply a mis-remembering of a drinking song and its various re-interpretations? An afterwardness? But of what? Of whom? And by whom? The 'I' and the 'you'. And 'it' - the song, its phonics and its sonics. Both of the song and within its sounds? A coincidence

62 H. Tracey, 'Catalogue - The Sound of Africa Series: 210 Long Playing Records of Music and Songs from Central, Eastern and Southern Africa', (Roodepoort: Frier \& Munro, 1973), 11.

63 P. (with I.) Mayer, Townsmen or Tribesmen: Conservatism and the Process of Urbanization in A South African City (Cape Town, London, New York and Toronto: Oxford University Press, David Philip and Namibia Scientific Society, 1971), $2^{\text {nd }}$ edition, vii.

64 Mowitt, Sounds, 35.

65 Iris Bodlani, telephonic interview with Sinazo Mtshemla, 27 September 2016.

66 D. Mdingi and Company, Ndinovalo Ndinomingimingi, ILAM, CR2969-GE78-42, Gallo Record Company, 1952. http:// greenstone.ilam.ru.ac.za/cgi-bin/library? $\mathrm{e}=\mathrm{q}-01000-00---0$ ilam--00-1--0-10-0---0---0prompt-10-DC--4-----0-11-11-en-50---20-about-ndinovalo--00-3-1-00-0011-1-0utfZz-8-00\&a $=\mathrm{d} \& \mathrm{c}=\mathrm{ilam} \& \mathrm{srp}=0 \& \mathrm{srn}=0 \& \mathrm{cl}=\mathrm{search} \& \mathrm{~d}=\mathrm{D} 11634$, last accessed 3 December 2016.

67 Interview between Gary Minkley and Eric Nomvete, 13 May 2000. 
or an echo? However heard, the song is resonant of a nervousness, an anxiety and a rejection, perhaps not simply in the 'I' and the 'you' but in the divided uncomradely 'we' of SAAWU. Is it resonant also with a crisis in perception, recorded, remembered, rejected, and invoked in its becoming, decaying and displacement through but not of Pondoland, in music festivals, memory and the ethnomusicological? An absence of words, an electrifying crackling and scratched song sound, and an abundance of associations and disassociations that can never quite be sounded out.

Perhaps then, not so much an indigenous 'soundmark'68 as an 'immanent vibration' ${ }^{69}$ Mowitt, following Aden Evens, suggests that sound, '... beyond its distinctive sonic and acoustic properties might also be grasped as a materialization of what lacks either beginning or end. In terms he [Evens] borrows from Gilles Deleuze, sound realizes the ontology of immanence; it locates it in the field of human perception while simultaneously pointing to the problem of delimiting such a field ... " [s] ound is a problem posing itself while working itself out"' ${ }^{70}$

It is also worth recalling Walter Benjamin's argument and Susan Buck-Morss' reading of this around the ways that 'an understanding of modern experience is neurological'. Moving from the 'synaesthetic system' and its subsequent development into a system of anaesthetics and a crisis in perception, she says it is '... no longer a question of educating the crude ear to hear music, but of giving it back hearing. It is no longer a question of training the eye to see beauty, but of restoring "perceptibility"' ${ }^{71}$ While it might be necessary to point out we are trying to develop a more critically extended reading, following Mowitt, of distinguishing between hearing and listening, the sense of her argument as one of anaesthesia is important.

Elsewhere in his argument, Mowitt has noted, in relation to Benjamin's use of echo as a potential keyword in the fight against historicism, that Benjamin wanted to 'split history' and Barthes to 'split sociology'. If, as he says, 'we split, as it were, the difference, we come rather abruptly to context and the problem of whether echo helps us think about literature or culture more broadly and society as articulations of delay, displacement, and decay .... ${ }^{72}$

However, 'Pondo Blues' is not even an 'unheard melody' in Red, at least in diegetic and in non-diegetic terms. It is neither performed nor soundtracked in the film, or in the installation. Its echo, rather, is in these nervous delays in the midst of what we are identifying as the anaesthetics in the hearing of but not listening to this liberation music and of the way its sonics can be listened to in the displacements of its harmonies and in the decay of its melody into the sounds of the city.

With due acknowledgement to Brett Pyper, this volume, drawing on the work of Murray Schafer, and as Pyper notes, a soundmark is an emblematic sound that is distinctive of a particular place.

69 Mowitt, Sounds, 136.

70 Mowitt, Sounds, 131.

71 S. Buck-Morss, 'Aesthetics and Anaesthetics: Walter Benjamin's Artwork Essay Reconsidered', October, Vol. 62 (Autumn, 1992 ), 18 (3-41). It is worth noting, as does Mowitt, that the tension between visualism and sound remains potentially problematic here, where Mowitt has suggested that it is important to consider Benjamin's use of voluntary and involuntary memory, rather than optical unconsciousness, 42-48.

Mowitt, Sounds, 34-5. 


\section{Red Soundtrack}

The film Red does, of course, have a soundtrack. And as an installation in the Ann Bryant Art Gallery, the unanticipated presence of the gallery's piano located un-played sound at the very centre of the installation. As an installation about art, politics and labour, to return to O'Toole's formulation, does it also then, sound 'the work of a revolution'? Or, as an unheard melody on the piano with its vase of red flowers? Does it strike a note of rejection, a renunciation? Or more?

Taken literally for the moment, the film's soundtrack, as Pyper (this volume) suggests, is largely ambient and understated and, Pyper argues, 'apart from the sounds of the narrators' voices, non-diegetic, underscoring the stillness of the visual material'. Pyper describes this aspect of the soundtrack, then, as being 'generic in character and includes sounds which appear 'incidental' to the process of visually documenting places around the Mercedes-Benz plant in East London, made up of ambient sounds of the sea, ship signals, wind, rustling leaves, traffic and trains which 'envelop, underscore and punctuate the narrative' contributing a contrapuntal sequence of contemplative impressions, inviting a reflection (and not immersion) on the place of these events. ${ }^{73}$ Neither are these descriptions complete, though, as a bracketed listening proposes: car doors slam, motors 'rev' as trucks start rolling, a siren shrills.

It is possible then, to listen for a different echo in this soundtrack of the city and the factory, of these sounds 'posed as a problem that is working itself out'? In part, if necessary, it can also be tracked to O'Toole's invocation of Gush as South Africa's Mayakovsky. As part of the Soviet revolutionary 'avant-garde' in the 1920s and 1930s, Mayakovsky and many other influential artists and filmmakers were immersed in what has been described as, in part, a sound revolution, attempting to develop a new proletarian aesthetic encompassing art, music, voice, radio, film and sound. ${ }^{74}$ At the same time synchronised sound-on-film or optical film sound emerged within filmmaking, the result of a complex series of trajectories and developments, particularly in the USA, Germany and in the USSR. This altered the temporal integrity of acoustic recordings. Alongside this, so too did synthetic sound, further changing the ontological stability of all recorded sound as tones from out of nowhere, further undermine recorded sounds' seeming indexicality. ${ }^{75}$

More importantly for our argument is the related sense in which Arseny Avraamov's Symphony of Sirens, partly influenced by Vladimir Mayakovsky's

73 See B. Pyper, 'Hearing Red', this volume, (5).

74 J. Maingard, 'Strategies of Representation in South African Anti-Apartheid Documentary Film and Video, 1976-1995', (D. Phil. Thesis, Wits University, 1998). In many respects, the film Red departs significantly from what she calls 'working class cinema in the 1920s and 1930s' in terms of figuring crowds, masses, leaders, participants and the collective, including concerns with 'collective production' and with the related forms of low-angle camerawork, an emphasis on movement and an overall sense of commitment, authenticity and the presence of the worker's voice (107-177). Read in these narrow visual and production terms, any connection to Red would be not just tenuous, but inappropriate and unproductive. However, the resonance of Mayakovsky, through Arseny Avraamov, to Dziga Vertov, to 'proletarian films' and to the documentary film does have an echo around sound where there is the attempt to 'keep commentary and excessive tampering with sound to a minimum'.

75 See T. Y. Levin, 'Sounds from Out of Nowhere: Rudolph Pfenninger and the Archaeology of Synthetic Sound, Grey Room, 12 (Summer 2003), 32-79. (61) 
writings ${ }^{76}$ monumentally anticipates the more circumscribed nature of soundtracks to what Carolyn Birdsall has called 'city films', which, in turn, we argue, has particular resonances in Red. Avraamov performed macro-concerts in urban spaces of Baku and Moscow (among others) in the USSR between 1921 and 1923, using the sounds and noises of cars, trains, boats, planes and artillery alongside workers' songs. ${ }^{77} \mathrm{He}$ had a portable machine built with tuned steam-driven sirens ("The SteamWhistle Machine') that could play the 'Internationale'. These macro-concerts, suggests Alarcón, were commemorations of the October Revolution, using the 'happy chaos' of the sounds of weapons, machines and workers heard on the night the Winter Palace in St. Petersburg was stormed, which the composer Avraamov remembered as a liberation both of the proletariat and of the machines subservient to the capitalist system..$^{78}$ Avraamov's ideas of creating proletarian music through sounds taken directly from factories and machines and from the city were seen as revolutionary at the time, and continue to be read as such. ${ }^{79}$ Primary among the Soviet avant-garde filmmakers concerned with revolutionary proletarian 'city films' was Dziga Vertov.

Birdsall locates the work of Vertov (and Joris Ivens and John Grierson's GPO Film Unit) as among the first filmmakers to fully explore the possibility of soundscape composition within documentary'. ${ }^{30}$ In tracing a concern with what Birdsall calls 'early experiments with documentary sound aesthetics' under the notion of a 'resounding' of particular silent films of the 1920s and of the politics of representing urban sound in the 1920s and 1930s, she suggests that three themes are centrally bound up with political investments in the documentary representation of urban sound. ${ }^{81}$ For her, these are outdoor recording (of original source sounds), montage editing and a thematic stress on workers' labour.

Furthermore, drawing on her discussion of Vertov's film, Man with a Movie Camera, she argues that it was originally conceived of as a 'sound film' alongside Vertov's formulations of a 'cinema eye' and a 'radio eye' - which were broader projects

76 The Wire Salon, April 2013, https://soundcloud.com/cafeoto/sets/the-wire-salon-synthesized, accessed 19 September 2016. Relatedly, consider the following: 'In Moscow in the 1930s, the composer and music theorist Arseny Avraamov, best known for his 1922 Symphony of Sirens, proposed vocalizing the writings of Lenin by synthesizing the voice of the Bolshevik leader, who had died in 1924, using graphical sound and other pioneering methods of audio synthesis. Later, in 1943, Avraamov argued against the new National Anthem of the Soviet Union, which replaced 'The Internationale' the following year, contending that the anthem of a revolutionary republic should be based on new approaches to harmony. Moreover, Avraamov proposed that the anthem should be performed by the Futurist writer and actor Vladimir Mayakovsky, who had died 13 years earlier. Avraamov proposed synthesizing Mayakovsky's voice in what he referred to as his Poetical Laboratory.'

77 M. M. Alarcón, Baku: Symphony of Sirens Sound: Experiments in the Russian Avant Garde. Original Documents and Reconstructions of 72 Key works of music, poetry and agitprop from the Russian AvantGardes (1908-1942), translated by Deirdre Mac Closkey (London: ReR Megacorp, 2008), 13; 16. http://monoskop.org/File:Baku_Symphony_of_Sirens_Sound_Experiments_in_The_ Russian_Avant-Garde.pdf, last accessed 3 December 2016.

78 Alarcón, Baku, 16.

79 Miguel M Alarcón. Baku: Symphony of Sirens Sound: Experiments in the Russian Avant Garde. Original Documents and Reconstructions of 72 Key Works of Music, Poetry and Agitprop from the Russian Avant Gardes (1908-1942). Translated by Deirdre Mac Closkey. (London: ReR Megacorp, 2008), 18-19. http://monoskop.org/File:Baku_Symphony_of_Sirens_Sound_ Experiments_in_The_Russian_Avant-Garde.pdf. Alarcon describes that Avraamov worked with choirs thousands strong, foghorns from the entire Caspian flotilla, two artillery batteries, several full infantry regiments, hydroplanes, 25 steam locomotives and whistles and all the factory sirens in the city when he composed and conducted his Symphony of Sirens. According to the author, Avraamov also conducted the symphony himself from a specially built tower, using signalling flags directed simultaneously toward the oil flotilla, the trains at the station, the shipyards, the transport vehicles and the workers' choirs.

80 C. Birdsall, 'Resounding City Films: Vertov, Ruttman and Early Experiments with Documentary Sound Aesthetics', in H. Rogers, (ed), Music and Sound in Documentary Film (New York and Oxon: Routledge, 2014), 22.

81 Birdsall, 'Resounding', discusses Vigo, Ruttman and Vertov. 22. 
intended to develop cinema as a dynamic art form in response to and for Soviet society in the wake of revolution, entailing a radical approach to filmmaking, with the recording of 'real events' of the city and the world of labour. ${ }^{82}$ For our purposes, two related aspects are important: the morning-to-night structuring by/of 'sound'; and the presence of what she calls 'imagined sound' - imaged through alarm bells, multiple movements of machines, superimpositions of a radio loudspeaker and the like. Man with a Movie Camera was subtitled 'a visual symphony' and Birdsall argues (drawing on Kurt London) that this and other 'city films' followed a symphonic sound structure (introduction - main and subsidiary theme - development - recapitulation - coda). Others, like Eisenstein, she suggests, 'drew on melody and rhythm for experiments in cinematic style and action. ${ }^{33}$

Certainly, we are not proposing that the film Red necessarily contains a 'full' exploration of soundscape composition, or that it is visually structured like a symphony, or even that it performs anything approximating the Symphony of Sirens. But there are resoundings, urban sounds, sound from morning to night, outdoor sounds, machines - automobiles, the sea, ships, cranes, phonics montaged between, behind and around the very audible and textual subtitled voices of the film.

In this regard, perhaps if conceived as a sound 'city film' with imagined sound, a film resounded, Red might be considered to audit the striking and subsequently dismissed - rejected - workers. Those who talk in the film are not these workers, but rather the intensely vocal, authorised voices, the one's that now sound the voices of capital and labour and of liberation. But for the dismissed workers, the sounds of Mercedes-Benz are from its outside, across the river, water tiding past, waves breaking off automobile carriers, cars moving at its gates, on the streets, and in its sonics: wakes, ships and fog horns, dirty winds, cranes moving, the occasional murmur of voices, trains rumbling past, cars driving by, the odd siren screeching, hooters, the hiss of the city of Mercedes. Read or perhaps heard (and also listened to) in one register, these are the sounds of unemployment, on the street, moving, job hunting, praying, always within the resonant sound of the assembly plant. Surrounding the assembly plant, yes, and certainly not on the inside of the factory and labour. Rogers observes that documentary sound is often typified as a lack of clarity of the sound track' and there is a sense here that there are no images, or sounds that are not, in some way, anchored to the factory, but from its outside.

The fact that these sounds are heard (and seen) as incidental, ambient and generic is reflective of the visual (as Pyper suggests) and might alter with a different posture of listening. The overall sense of mute-ness is important, as these city sounds constantly run in-between, alongside and behind the phonics of the montaged interviews. There is no doubt much more to say about these (see also Witz and Pyper this volume), but we wish to attend to the 'city sounds' of Red here. 
Two sounds in particular - the hiss and the murmur - need to be listened to. At one level, the muted, almost incidental, murmur of sounds and voices. At another, fragmentary, seemingly unstructured, random sounds - an ambient hiss?

Murmur first. The Red soundtrack murmurs with a low, continuous background noise of the city and its voices. Is this the decay of the sound of liberation - liberation fallen apart - and of the worker as expendable, reduced to inaudible utterances and indistinct sounds? Put differently, is it, in part, what remains of song and voice, of what can be heard within the loud phonic texts of politics and history, tuned here to the Mercedes plant and the red Mercedes? As John Mowitt has reminded us, for Foucault the murmur is deployed to '... get at what is unreason in reason, the unthought'. And as Foucault argued, the murmur locates the necessary 'absence of history' enabling its possibility, 'without any speaking subject ... collapsing before it reaches any formulation. ${ }^{34}$ Lauri Siisiäinen has characterised this status of murmur in Foucault as simultaneously underlining the anonymity of discourse, with the absence of a 'sovereign subject' at its centre, while also referring to the idea of subject or consciousness that precedes or constitutes discourse.$^{85} \mathrm{He}$ proposes, via Foucault, then, that ' $[\mathrm{n}]$ oise/murmur is a multiplicity, which is characterised by indeterminancy'. ${ }^{86}$

For Mowitt, as well, though, '... Foucault uses the distinction between language and murmuring to reiterate that between reason and unreason, the figure of the insect swells. ${ }^{87}$ Perhaps, then, the murmur in Red and its sounding of the absence of the speaking subject of the dismissed, redundant, indeed migrant (between red and schooled) worker resonates back to the hearing within NUMSA as the plagued sound of 'feeding locusts'. The posture of this listening to its murmurs, though, folds within it the voice of the sovereign subject - the urban, working, unionised and liberated worker subject - and its return to the silence of this unreason which it has never 'shaken off'. The locusts' murmur in Red sounds the unthought of history and politics, the limits of its language and its necessary exclusions, and how it, in turn, reduces its own unintelligibility to an insect's murmur. Its 'silence' is a noise.

Perhaps, though, it is also a soundtrack resonant of denial and desire, more an echo of the car itself as it assembles the sounds of its use and what this 'purports to know' (Mowitt) - 'out of the reach of most people. ${ }^{88}$ Indeed, it is tempting to speculatively reconstruct the filming of Red from within the Mercedes motor-car, muted, practically silent, where the machine sounds of its production are displaced into what is routinely described as its 'eerily too quiet' and 'still' 'smooth' cabin noise. ${ }^{89}$ Silence?

84 Mowitt, Sounds, 60, quoting Michel Foucault's Preface to the History of Madness: '... The plenitude of history is only possible in the space, both empty and peopled at the same time, of all the words without language that appear to anyone who lends an ear, as a dull sound from beneath history, the obstinate murmur of a language talking to itself - without any speaking subject and without an interlocutor, wrapped up in itself, with a lump in its throat, collapsing before it ever reaches any formulation and returning without a fuss to the silence it never shook off. The charred root of meaning. (xxxi-ii)'. For Mowitt, this enables a further consideration of murmur in relation to whisper and to the disciplinary 'provocation of whispering.

L. Siisiäinen, Foucault and the Politics of Hearing (London and New York, Routledge, 2013), 17.

Siisiäinen, Foucault, 18.

7 Mowitt, Sounds, 61

88 See for example, The Elevating Sound website, http://elevatingsound.com/your-guide-to-getting-a-quiet-car/e website, last accessed 2 October 2016

89 Elevating Sound website. 
Bijsterveld et al have argued that the engineering obsession with producing silence in cars is related to the need to 'hear' ominous signs of malfunction..$^{90}$

As Paul Carter has noted, the sound of a car passing, for example, is neither periodic, nor random, which he suggests, are the two classes of sound favoured by hearing culture 'research' (as sinusoidal tones or sudden noise bursts, their differentiation, and their grouping, repetition or counterpoint as events are seen to suggest larger auditory consciousness) as they stand out from 'the background noise. ${ }^{91}$ In Red, though, it is this 'background', this predominant sound of vehicles (on road and sea) that is heard. Itself a hiss.

This vehicle noise is punctuated by what we want to call an associated hiss, often sounding like old recordings, or of 'projector sound'. While it might be possible to consider what the 'hiss of technology's history' might further mean in Red, it also suggests how the hiss of the automobile is the noise signifier of technology's historical sound presence. This hiss is distinguishable from the first five seconds and last minute of 'dead air' in the film. Outside of, or is it within these brackets, there is the hiss, without linear development and which reminds us, at least, in part, that sounds 'begin and end in noise, ${ }^{92}$ not in silence. And that there is no beginning and no end to this hiss, this noise. Carter calls this the 'attached hearing' of his[s]tory, the hiss of history which calls History and its desire to 'hear the other in silence' into question.

If we are correct that the hiss of the film Red is the hiss of the automobile, the Mercedes, perhaps we can be permitted one last audit. In the installation Red, Gush, as is well rehearsed, disassembles a red Mercedes, breaking it down into various body parts (and imaginatively reconstructs the labour of the sit-in strike in order to think differently about meanings of work and time). Yet, if one were to drive a Mercedes, or any car for that matter, a hiss is a signifier of a fault, a breakdown, of the engine disassembling from its purpose. It is a sign, a sound of 'over-heating', or of 'leaking, ${ }^{\text {'93 }}$ the unexpected. ${ }^{94} \mathrm{An}$ immanent vibration of disapproval, that, to return to its etymology, calls into question 'learning or finding out by experience' and its claims to 'truth' and 'correctness. ${ }^{95}$

The Mandela red Mercedes had only six faults, not the usual and routine $76 .{ }^{96}$ But which of these faults sounded this hiss? Perhaps then, Red as an installation a work of art, including the film Red - helps us to hear the sounds that History, Sociology, Politics and indeed Ethnomusicology and Music/Sound Studies do not know. In listening to Red we hear History's limits. Not the work of a revolution then, but perhaps a revolution in the sound of work and a change in the strange work of sound - listening to liberation.

K. Bijsterveld, E, Cleophas, S. Crebs, and G. Mom, Sound and Safe: A History of Listening behind the Wheel (Oxford: Oxford University Press, 2014).

91 P. Carter, 'Ambiguous Traces, Mishearing, and Auditory Space', in V. Erlmann, (ed), Hearing Cultures: Essays on Sound, Listening and Modernity (Oxford and New York: berg Publishers, 2005), 43-64 (59-60).

92 Carter, 'Ambiguous Traces', 62.

93 In Red, Groom and Fikizolo, when discussing the building of the car, say 'the bolts, the nuts and bolts, tyres and everything that ... the underneath of the car is fine, it's not leaking, it's not having, not doing anything. 40:01 minutes. Perhaps ...

94 See the Automobile Association (AA) website, http://www.aalcar.com/library/5_car_noises.htm, last accessed 3 October 2016. Approval, from prove, Middle English, from Anglo-French apruer, approver, from Latin approbare, from ad+probare to prove: 'to learn or find out by experience'; to test the truth, validity, or genuineness of. 